\title{
The cleansing of the leper in Mark 1:40-45 and the secrecy motif: An African ecclesial context
}

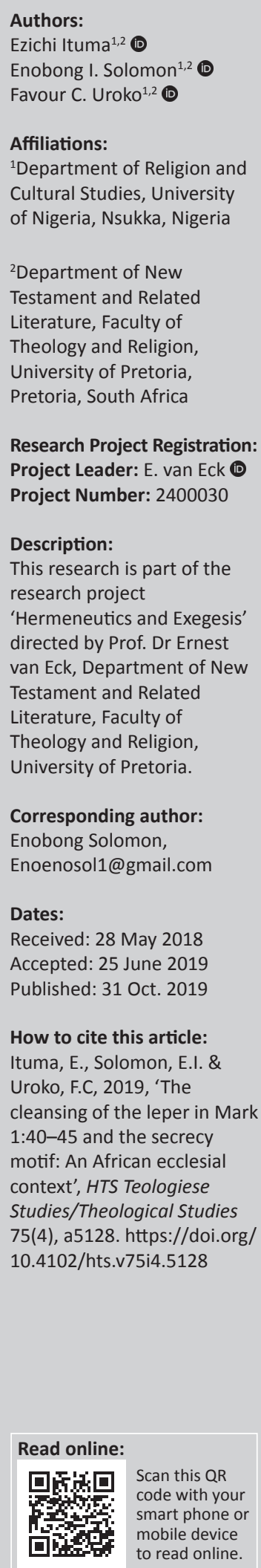

This article examines the reason behind the charge to secrecy imposed by Jesus on the leper in Mark 1:40-45, in the context of African experience, the implications of the meaning conveyed and the challenges posed on the church and the gospel enterprise in Africa. The ministry of Jesus could have been a platform for conflicts, self-glorification, hero worship and exploitation. Jesus resisted the temptation in those directions. The charge to silence in African context reveals the virtue of silence which is subsumed in integrity, modesty and character (trust and accountability). It calls the attention of the followers of Jesus to the worthiness of emulating such a lifestyle as a pattern for service to God and humanity. The textual and historical exegetical methodology is adopted in this research.

Keywords: Leper; Church; Ecclesial; Secrecy motif; Mark.

\section{Introduction}

In New Testament scholarship, the narrative of the healing of the leper in Mark 2:40-45 is grouped within Vincent Taylor's 'Miracle Stories' (Taylor 1953:195), while Dibelius calls it 'Tales' (Dibelius 1982:24). Textually, its strength of authenticity is the strong support it derives from codices Saniticus, Allexandrinus and Vaticanus - very ancient manuscripts. These are 4th and 5th century uncial manuscripts highly valued in biblical scholarship. The fact that this narrative is recorded in $Q$ also reduces criticisms against its authenticity. Leprosy in the Old Testament is seen as a form of physical and spiritual pollution, with social stigma. In the generic structure of form critical analysis, the desperate condition of the leper is noticeable in the manner he knelt down at the feet of Jesus. The miraculous act, and the spontaneous recovery, presents Jesus as 'a colossus and embodiment of divine strength that transcends all human imagination and natural phenomena' (Ituma 2001:204).

The crux of this research lies in William Wrede's theory of the 'Messianic Secret' motif. According to him, Jesus sent the healed man away instructing him Mark away at not to tell it to anyone. Thus it reads: "But go, show yourself to the priest and offer sacrifices that Moses commanded for your cleansing as a testimony to them' (Mk 1:42-43 NIV).

African scholars have contributed much in doing Christology from within the African context. However, Jesus to the Africans is not in succinct names and titles (Gwamma 2008):

African scholars must be able to ask their own questions and provide their own answers in respect to their understanding of the biblical text of how it conveys meaning to them. (p. 136)

The Jesus of the Bible is one whose life, time and context have much to do with Africans. African nations are bedevilled by the problems of leadership, hunger, poverty, sickness and diseases. In Nigeria, as in most African countries, there is 'the dearth of selfless leadership, leadership with foresight, and transformational leadership' (Babatope 2018) and ever increasing hunger, and extreme poverty is a reality (Ucha 2010). The Jesus of the Bible is one whose life provides a model in servant leadership, whose ministry offers hope, compassion and restoration. His life and ministry connect with contemporary African situations. The objective of the research therefore is to examine the reason behind the charge to secrecy imposed by Jesus on the leper in the context of African experience, its implications and challenges to the church and gospel ministry in Africa. To be presented succinctly in questions, why should Jesus warn the man not to herald the good he had done to him? Was Jesus' warning and command to silence a messianic strategy or an act of modesty? What is the African perception of the charge to silence? Is there any lesson implied for the church in Africa? These are the questions this research seeks to resolve. In view of the need to capture the historical context of the text, it became necessary to apply textual and historical exegetical methodology in the research.

Copyright: @ 2019. The Authors. Licensee: AOSIS. This work is licensed under the Creative Commons Attribution License. 


\section{The 'Messianic Secret' motif}

In Mark's gospel, Jesus is constantly portrayed as keeping secret his messianic identity. This he does by commanding demons not to disclose his divine identity. At other instances, he charges beneficiaries of his healings not to mention their healings to others. In Jairus' house (Mk 5:35-43), Jesus resuscitates a girl from death. The order

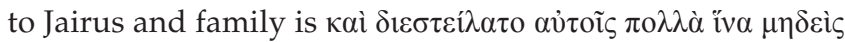

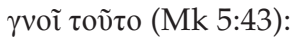

[And he instructed them that no one should know about this].

Healing the deaf and deaf man (Mk 7:31-36), the injunction to those who brought him is, verse 36

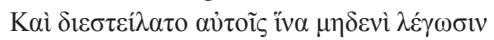

(And he instructed that they should tell no one).

To the healed blind man at Bethsaida (Mk 8:22-26), the charge is,

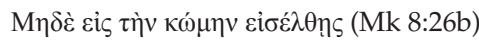

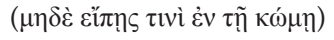

Not into the village may you enter (nor tell it to anyone in the village).

At other instances he charges beneficiaries of his healings not to mention their healings to others. In some other occasions, the charge to silence is imposed on his disciples. This concealing of his messianic identity by Jesus has come to be known as the 'Messianic Secret'. According to Dunn, the 'Messianic Secret' motif was first employed by William Wrede in 1901 to explain why Jesus repeatedly told people not to disclose what he has done and who he was (Dunn 1970:97). In the words of Eric Mason, the 'Messianic Secret' refers to the motif, chiefly in the Gospel of Mark, in which Jesus is presented as suppressing the knowledge of his identity (Hamil 2011:11).

\section{Wrede's explanation to the Messianic Secret motif}

Wrede categorises the injunctions to silence into five: prohibitions addressed to demons (Mk 1:25, 34; 3:12), prohibitions following (other) miracles (Mk 1:43-45; 5:43; 7:36; 8:26), prohibitions after Peter's confession (Mk 8:30; 9:9), intentional preservation of his incognito ( $\mathrm{Mk} 7: 24 ; 9: 30)$ and prohibition to speak which did not originate with Jesus (Mk 10:47) (Greig 1971).

By examining these prohibitions Wrede came to the conclusion that the idea of the 'Messianic Secret' is wholly a theological idea. Jesus did not in fact claim to be the Messiah during his ministry and it was not until after his resurrection that his messianic status was affirmed by the Christian community and that the 'Messianic Secret' is nothing other than a literary strategy employed by Mark to account for the absence of messianic claims by Jesus himself. Wrede argued that the historical Jesus never claimed to be the messiah, but the postresurrection conviction in early Christianity of Jesus' divinity and messianic identity caused the Church to rework genuine reminiscences of Jesus to express this theology (Greig 1971:11). The motif is not Wrede's theory. It is an attempt at providing an explanation to the observable evidence of secrecy in
Mark's gospel. Tim Widowfield (2013) provides a clearer understanding in this direction:

The motif in itself is not Wrede's theory. It is observable evidence. Wrede's theory is about seeking the best explanation for the presence of the motif. By Secret, Wrede did not simply mean concealment of facts. In German, Geheimns also connotes 'mystery'. We may rightly think of the 'messianic secret' broadly as the theme of the (mysterious concealment of Christ's true identity in Mark. And to a lesser extent the other synoptic Gospels. By motif we mean a 'theme'. It could be a narrative device, a theological contrivance, or a historical theme (i.e. an authentic habit of the historical Jesus preserved in Mark's tradition). (p. 20)

Since the publication of Wrede's work The Messianic Secret, the secrecy motif in Mark's gospel has become a subject of concern to, and drawn criticisms from, New Testament scholars.

\section{Goodacre (2010) noted:}

This theory has continued to meet sharp criticisms over more than one hundred years after its initial publication and over forty years since its translation to English. Even though Wredes' primary conclusions were quickly oppugned, it remains true that Wrede brought a motif of secrecy to the forefronts of the minds of gospel scholars. (p. 20)

Wrede's work found its earliest critique in William Sanday. Sanday expressed utter astonishment with Wrede's theory. He questioned Wrede's use of the resurrection as a cover-up conspiracy, and argued that if a resurrection faith existed at all, such was only possible because the people witnessed a historical resurrection. He therefore adjudged Wrede's view of the Easter faith as 'utterly superficial and impossible' (Sanday 1907:100). Another critique of Wrede, N.T. Wright, viewed Wrede's explanation for the Messianic Secret as implausible. According to Wright (1996):

... Jesus asks his followers about the general public opinion of him and his work; they all tell him that he is thought of as a prophet. But who do they think he is? The Messiah. (p. 529)

Jesus sternly commands them not to repeat this to anyone. Wright argued that Jesus was conscious of his Messiahship and that his disciples understood him as such (Wright 1996:529).

In the attempt at resolving the problem of the Messianic Secret motif, scholars have argued that there are other plausible explanations to the secrecy motif other than Wrede's claims. Dunn noted that an analysis of Wrede's theory reveals that it cannot sufficiently and satisfactorily account for instances where Jesus allowed for the spread of the news of his miracles (Dunn 1971). Wright, examining the political background at the time of Jesus, is of the opinion that the messianic secret motif can rightly be understood from the background of the political connotations that surrounded the title of messiah. He stated that (Wright 1996):

... [O]nce Jesus was thought of as a potential or would be Messiah, the movement would swiftly attract attention of the 
wrong sort. Herod has already heard about Jesus, and reckoned he was a prophet of sorts. If he had known more, he might not have been content with merely 'hoping to see him'. Jesus spoke about Herod, and about John and himself in relation to himself and in relation to Herod, in ways which implied an awareness that he was making a claim which Herod would find threatening. (p. 529)

Richards (1983) argues that the secrecy theme is historical and stems from the life of the historical Jesus.

The social conditions created a revolution-ready class who would have brought Jesus into conflict with the government of the time. He opines that a strong case can be made that Jesus issued these commands to silence, to suppress the illegitimate fervour of the mobs of people who wanted to take Jesus by force and make him King.

To him, the crowds were a volatile social group with the ability to swell into a political insurrection. Jesus was stalked by this mob of people and because of their understandable revolutionary mindset, he issued commands to silence (Richards 1983).

Dopoe suggests that there are several corroborative reasons which can account for the motif of secrecy in Mark's gospel that does not compromise the historicity or the message of the gospel. Accordingly, he opined that secrecy could have been implemented because Jesus did not wish to be renowned for being a worker of miracles. Further, he stated that faith based upon miraculous exhibition is not faith in the person and message but rather on the miracles he performs; Jesus wished to keep his Messiahship and miraculous works secret so that he could share the gospel, instead of falling prey to the inescapable connotations of being a miracle worker; and Jesus may have exercised the messianic secret to shift away from the popular connotations associated with messiah (Dopoe n.y.:51).

In The Synoptic Gospels Today, Joseph Kudasiewtz opined that the fact of the 'Messianic Secret' goes back to Jesus himself who had the messianic consciousness and lived as a hidden messiah. He lucidly observed that (Kudasiewicz 1996):

Those commands to keep silence find their natural explanation in the life situation of Jesus, in the historic-religious circumstances of his environment and they were given to prevent an erroneous understanding of messianism and undesirable reactions of the people. (p. 13)

A social perspective to the problem of the secrecy motif given by Pilch and Malina (1998) in the Handbook of Biblical Social Values states that:

There was an even more primary social reason for Jesus hesitation for word to spread of himself and his work. Three paradigms that come into play; Envy-the begrudging of possession of some quality or object; Limited good-the ancient perception that all good things are limited and finite in quality, including intangibles like; Honour-the accord given by a person to others, a value in the ancient world that they took ... seriously ... Jesus reticence is an example of what would have been regarded as honourable behaviour in the ancient world. (p. 118)

Jesus' charge to silence was a deliberate avoidance of the conflicts that could have been motivated by envy as a result of the unrestricted publication of his miracles. He operated in the consciousness of the fact that 'the charm of all power is modesty' (Alcott 2012:1).

The theme of the 'Messianic Secret' motif is brought to attention in the context of African Christology by Onwu in his work Critical Introduction to the Traditions of Jesus. He presents a paradigm shift which is captured in the poser: 'How may this secrecy motif be understood in contemporary African Ecclesial community?' (Onwu 2002:70):

The secrecy motif in the African ecclesial context represents an imperative summon to humility, selfless sacrifice, faith, commitment to Jesus as Saviour. Precisely it is a critique against the prevailing pride and lack of faith in some African Christians of today. (Onwu 2002:72)

\section{Historical background and situation}

In order to appropriately situate the ministry of Jesus, it is essential to understand the political, along with the socio-economic, context of the times in which he functioned (Hanson \& Oakman 1998):

First century Palestine was besides being an advanced agrarian society, shaped by several dominant forces: the Israelite tradition (linguistic, cultural, and religious heritage), the Roman Empire (political control) and Hellenism (the pervasive cultural influence over the whole Mediterranean and the Middle East). (p. 7)

The historical setting of the periscope falls within the period of Roman occupation of Israel. Politically, the Roman established a two-tiered system of government consisting of Roman overseers and Jewish leaders who exercised control in the name of Rome. For the Jews, religion and politics were intertwined. Thus, they had come to expect a Messiah who would lead and free them from foreign domination. The political arrangement created a social stratification of the 'rich' and 'poor'. The peasantry class in particular was resentful about the Roman occupation and taxation with distrust for their leader (political and religious leaders). Jewish identity rested on stories of the Patriarchs (Abraham, Isaac and Jacob) as well as the Exodus from Egypt. The conviction expressed in the belief that they were God's chosen people sustained this identity. Jesse Richards points out that 'the common people terrorized by the Roman annexation, oppressed by heavy taxation and led by a corrupt aristocracy yearned for a new king like David' (Richards 1983).

Galilean economy was shaped by the interplay of the forces of political control and the cultural heritage of its people. Scholars differ on the economic status of Galilee, and the condition of the ordinary Jesus. Among many, it is accepted that the Galilee in which Jesus was born and raised was plagued by poverty ... and that his audience was made up of 
the masses of the poor (Crosan, 1998:3). This agreement is premised on the inequality that characterised most societies in the ancient world. Finley noted that the most troublesome inequality was not between town and country, not between classes, but simply between rich and poor' (Finley 1999:152). This inequality was strengthened by the socio-economic policy of the Roman Empire.

United states, like the Judean kingdom, were a main source of revenue through taxes. Considering the urbanisation drive at the time of Herod Antipas and Galilean Archaeology, 'others have argued that Galilee was an egalitarian and economically prosperous society' Overman (1997:67).

Herod Antipas invested extensively in the cities of the Judean kingdom through the construction of large building projects of architecture and other public structures. Aviam averred that these urbanisation drives 'provided employment, stimulated trade, and in general raised the level of prosperity' Aviam (2013:5).

Archaeological findings show evidence of inhabitants who were wealthy, and evidence of industry and items that suggest affluence. Based on these, Aviam inferred that the Galileans were engaged in vigorous trade, which does not support a portrait of a half-starved peasant the typical Galilean' (Aviam cited in Fiensy \& Hawkings 2013).

Wealth was based on ownership of land. However, the economic policy of the time made it that most land was owned by a few wealthy elite families, who rented land to tenant farmers. These tenant farmers utilised family members and slaves, who formed the peasantry class. According to Oakman (2008):

\begin{abstract}
A peasantry is a rural population, usually including those not directly engaged in tilling the soil, who are compelled to give up their agricultural (or other economic) surplus to a separate group of power holders ... peasants have very little control over their political and economic situation ... the overlords of the peasants tended to be city dwellers, and a culture-chasm divided the literate elite from the unlettered villager. (p. 167)
\end{abstract}

Elite families were more in the cities. The peasants were the masses who lived in the villages (Hanson \& Oakman 1998):

$[U]$ rban elites, whether Romans or Judeans, decided both domestic and foreign polices with little attention paid to the majority of peasants who lived in the villages. Taxes and tolls, and tributes were imposed from above; and they were not collected to the benefit of the populace but only elites. (p. 61)

Another important aspect of Palestinian economy was fishing. The Galilean fishing enterprise was not a free one. Galilean fishing was highly regulated, taxed and controlled by the elite class, who sold fishing rights to brokers. Hanson further noted that 'the fishers could hardly be classed as "entrepreneurs" in such a highly regulated, taxed, and hierarchical political economy' (Hanson 2009:n.p). The fishing business was therefore regulated to be an elite profiting enterprise, where the real labourers were exploited through tax and tolls. Hakkinen (2016:45) noted that the building projects demanded a lot more taxes and forced labour and made life even more difficult' especially for the rural masses.

An overview of the sociopolitical and economic situation in 1st-century Palestine portrays a society whose politics and economic policies created a culture-chasm between the rich and the poor. A society where wealth was in the hands of the ruling elites, while the rural dwellers (masses) were largely poor, deprived and without a voice. Among the Jews, these were the expectation of divine intervention by a messiah.

This societal portrait mirrors the contemporary African society. In most African nations, there is political instability, there is poverty in the midst of affluence among the ruling class. The general people are deprived and without a voice. The populace resent the leadership whether political or religious.

Oyesola (2007:553) averred that 'poverty is present everywhere but the kind in Africa is of a great magnitude both in its spread and destitutive dimension'.

In Nigeria, there is a widening gap between the rich and the poor. There is a discernible contradiction between the wealth of the nation and the living condition of the people:

Nigeria is Africa's biggest economy but it has more people living in extreme poverty than anywhere else in the world ... but Nigeria also pulls its weight on the other end of the scale, with arguably more millionaires and billionaires than any other African nation. (Anver 2018:1)

The people in authority and position steal from the commonwealth. They do not grow the economy by creating enterprises; rather the looted funds are stacked away in foreign banks.

The staggering waves of violence across Africa, the insecurity, economic recession, kidnappings and political upheavals are attributable to poor leadership. In a situation such as this, people become vulnerable and open to any form of intervention, especially if it is spiritual. Influx to miracle centres, deliverance programmes and healing crusades portray the frustration of the masses and the quest for divine intervention (the people have lost faith in leadership whether political or religious)

In Mark's Gospel, the crowd was originally drawn to the preaching and baptism of John. 'The whole Judean country side went out to him ...' (Mk 1:5). Subsequently, the crowds became attracted to the teaching and miracles of Jesus. Jesse Richard noted that at the time of Jesus' ministry, 'The crowds were a volatile social group with the ability to swell ..., into a political insurrection' (Richards 1983). Thus, Jesus' ministry risked political hijacking.

Wright argues that (Wright 1996): 
[I]f we understand the crowed as a mob zealous for a different king, it makes sense that Jesus was in danger of being made a leader of a revolt movement by the common people. (p. 535)

In the purity system of Judaism, lepers came under the injunctions of the Torah and temple regulations.

Lepers were oppressed socially, religiously, economically and psychologically. They were socially ostracised, regarded as unclean and untouchable. They were frustrated religiously as they were denied fellowship in the assembly of Yahweh. Psychologically, their condition was hopeless because their healing was considered impossible. The Mosaic Law and their interpretation legitimised the stratification of society, using extensive purity regulations. Economically, they were grouped among the very poor of the society. In Jewish worldview, only God could heal the leper. The priest could only declare them clean, but only God could heal (Matthew n.y.).

In order to appropriately situate the ministry of Jesus, it is essential to understand the political and socio-economic context of the times in which he functioned. First-century Palestine was, besides being an advanced agrarian society, shaped by several dominant forces: the Israelite tradition (linguistic, cultural and religious heritage), the Roman Empire (political control) and Hellenism (the pervasive cultural influence over the whole Mediterranean and the Middle East) (Hanson \& Oakman 1998:7).

\section{Perspectives on miracle healings}

Sickness and disease is a common problem of humanity in all places and times. However, people's perceptions of heath and sickness vary according to their cultural and social contexts. The Graeco-Roman world held different views on the causes of sickness. According to one case, the Graeco-Roman philosophers viewed sickness primarily as a misfortune because of natural causes. But to the vast majority sickness seemed to be a calamity abnormally brought upon humanity by some external power Case (1923:238).

From Plato to the stoics, 'Health and disease stood to one another in the relation of natural concomitants' (Shirley 1923:240). Health and sickness were an essential part of the natural order or the will of a supreme providence. But among the vast majority, sickness had a spiritual, rather than a natural cause. The idea of the supernatural cause of sickness was also common among the Jews.

These varying attitudes and opinions influenced the nature of remedy sought, but mostly, in an appeal to deity. Accordingly, there were various healing cults and healers in the time of Jesus. The healing ministry of Jesus was contextualised in a culture that was already familiar with the supernatural. There are records of numerous healing cults, healers and exorcists - some of them Greek, Roman and Jewish - during the period of Jesus' ministry.
Popular among the healing deities was Asclepius, whose cult was widely spread and practised throughout the GraecoRoman world. Their interventions involved the ritual of incubation as was the practice in the Asclepius cult. Focusing on the curative features that defined the image of Asclepius, Panagiotidou (2016) noted that:

His healing powers and the activities he was believed to perform to the supplicants during incubation...depicted in the healing inscriptions in the asclepieia...mediated the popularity of his cult and directly contributed to the attraction of the numerous supplicants to his temple. (p. 105)

As in many other cults of the time, the mode of intervention was ritualistic, accompanied by propagation mechanisms that gave popularity to the deities. Also there were historical personalities, such as Patriarch, Vespian and Appolonius Tyana, who were credited with healing powers. A miracle story recorded by Iacitus (AD 114-117) is that of Vespian, of the healing of a blind and a lame person. The fact that the miracle account is also recorded by Suetonius suggests that the story had a wide coverage.

However, Meier (1994:594) argued that Vespasian did not belong to the rightful line of emperors, and that the miracle story was meant to give indisputable legitimacy, which Vespasian needed as he travelled from Judea via Alexandria to Rome. Meier concluded that (1994):

Suetonius and Tacitus seem to tell the whole story with a twinkle in their eye and smiles on their lips, an attitude probably shared by Vespasian. The whole event looks like a 1st-century equivalent of a 'photo opportunity' staged by Vespasian's PR team to give the new emperor divine legitimacy - courtesy of god Serapion, who supposedly commanded the two men to go to Vespasian. Again, both in content and in form, we are far from the miracle traditions of the Four Gospels - to say nothing of the overall pattern of Jesus' ministry into which his miracles fit. (p. 594)

\section{According to Dickson (2008):}

Virtually all experts on the history of Jesus-whether Jewish, Agnostic or Christian-agree that the man from Nazareth performed deeds which his contemporaries interpreted as miraculous. That he enjoyed the reputation as a healer is beyond dispute.

The tradition of Jesus is supported historically. His method as a rule was to speak the word. He sometimes touched the patient and sometimes he cured at a distance. Whatever method he used, the recovery was generally immediate.

In approach, his goal was the restoration of the afflicted to a state of well-being and re-integration into their families and communities:

The fact that Jesus 'touched' the leper is significant. This was not necessary for Jesus to perform the miracle. However, being touched was extremely meaningful to a person with leprosy. Jesus personalized his encounter to meet their deepest needs. (Jerome Commentary:601) 
The leper, being socially ostracised, emotionally traumatised and spiritually alienated, needed more than physical health. Jesus' 'touch' demonstrated Christ's concern for the leper's restoration to physical health, social re-integration and spiritual wellness.

The attitude towards miracle healings is strangely that of belief and unbelief. In Christianity, the common view is that miracle healings are natural manifestations and demonstration of the power of God. However, there is the dispensational disputation that rules out the possibility of miracles happening in the present time. This dispute has been widely debated in theological circles since early Christianity. Cessationists argue that the supernatural gifts were adapted to the time of the apostles for a sign. They hold the view that the supernatural gifts of the spirit ceased when the scriptures were complete, because they were only needed as affirmations for the message of the gospel. Within the Christian tradition, two schools of thoughts have emerged: cessationism and continuationism.

Athanasuis (Bishop of Alexandria: 328-373 AD), Chrysostom (347-407 AD), Calvin and Luther are among Christian leaders with cessationist perspective. Continualists argue that the supernatural gifts of the spirit continue in the present time, manifesting in the gifts such as speaking in tongues, prophecy and miracle healings. Ter Haar (2003:413) reveals thus: "We are informed about healing miracles, apparitions and revelations, stigmatism, resurrection from the dead, and even virgin birth. It has sometimes been suggested that the belief in miracles has revived in recent years, due to the spread of neo-pentecostal or charismatic movement." That miracles ceased with the apostolic foundation of the church has been challenged by the claims of miracle healings among Pentecostals and charismatic movements.

African indigenous churches align themselves with these claims.

The effects of this debate still influence Christians' views on miracle healings. While some hold the cessationist view, a good number of others hold the view that the supernatural gifts of the Spirit are still operational in the present-day church.

Africans are at home with miracle healings. Supernatural manifestations fit into a cultural context that Africans are accustomed to. Divine intervention in the face of human afflictions is at the care of African belief system. Hence, Africans appear to be particularly receptive to miracles.

In Nigeria today, there is a strong attraction for miracles, which is evidenced in the proliferation of healing and prayer ministries, with their priest healers.

\section{The command to silence: An African context}

Silence is generally perceived to mean the absence of speech, words or being quiet. Keith Basso, one of the earliest investigators of the study of silence, opined that 'It is not the case that a man who is silent says nothing' (Keith 1970:213). He opined that silence was used in a different way among the Athabaskan-speaking people of western Apache in East central Arizona. Sobkowzak (1997) identified five categories in the act of silence within communicative contexts: refraining from speech, absence of sound, withholding knowledge, failure to communicate, and oblivion or obscurity.

This categorisation suggests that silence is a negative undesirable act, opposing what is normal and should be, philosophers and writers have argued, against these negative perceptions (Keith 1970). Zembyles and Michaelides (2004) argued that:

Silence is best understood as positive not a negative phenomenon. It carries meaning by the virtue of it being an absence; it can say something by leaning unsaid. (p. 193)

Silence conveys both positive and negative meanings. It has many meanings in the various speech cultures and is an intrinsic part of communication. As language is a carrier of culture, so does silence act as the mirror of the different cultural beliefs and values of people.

In Western cultures, silence is perceived as the absence of speech and may be interpreted as 'a mark of oppression Denial of self, dependency and at best immaturity' (Yancy \& Spooner 1994:298). This negative view held in Western cultures tends to take silence as a sign of indifference, anger, oppression, objection and even hostility.

In Africa, the silence of divine kings was imposed for the protection of the people. The institution of divine kings cut across sub-Saharan Africa. Divine kings are humans who stand between the worlds of humans and the divine.

As noted by Peck (1994), formerly in the Benin Kingdom in Nigeria, the Oba was restricted to the palace. Seldom seen in public, the Oba was regarded as the supreme leader of this world and the voice of the spirit world. Furthermore, according to Peek, the voice of the Oba was associated primarily with the utterance of curses or death sentence, the ultimate expression of supreme authority. If its utterance was the condemnation of a human to death, perhaps it is that the divine king is not just silent but has been silenced for the protection of all (Peek 1994:477).

The restriction from public appearance and utterance denotes protection and indicates restraint, reservation and self-control.

Silence is specifically linked to secrecy. Secrets are maintained in silence. Indeed, to be silent is to be secretive, kklme. 'There are, of course, traditions everywhere of what cannot be said in certain situations, but prohibition on speech seem $[s]$ more exacting and strict in African societies' Peek (1994:478).

Among Africans, social groups have secrets that make for their identity and which differentiate them from others. At the 
level of mystery, secrecy is associated with kings, traditional healers, priests, etc.; their office requires that they keep secrets; secrecy carries with it the burden of accountability of trust and modesty. Zahan (1979) aptly submitted that:

It [silence] is the supreme virtue, as it subsumes integrity, courage, the power of the soul, prudence, modesty, and temperance. Silence defines the man of character, and is the attribute of the wise man; it is a type of wisdom. He who knows how to be silent possesses true happiness, interior peace, and detachment. (p. 113)

Silence is the force in secrecy. In African thought, both are highly esteemed. As virtues, silence and secrecy subsume modesty, integrity, prudence, temperance or self-control and humility. Associated with these virtues are the responsibility, trust and accountability.

The imposition of silence on the leper by Jesus was therefore a charge to virtue, accountability and trust.

The good news that Jesus brought to mankind was not meant for the salvation of soul only. It was the good news of humanity's liberation from all manners of suffering and political injustices. The church has the mandate to bring the gospel of liberation to all people of every culture and race.

\section{The significance of miracles in the ministry of Jesus}

The working of miracles was an integral aspect of Christ's proclamation of the kingdom of God. Jesus said about himself that:

The spirit of the Lord is on me, because he has anointed me to preach good news to the poor. He has sent me to proclaim freedom to the prisoners and recovery of sight to the blind, to release the oppressed for the prisoners and recovery of sight for the blind, to release the oppressed. (Lk.4:18 [NIV])

\section{According to Onwu (2002):}

The oppressed are those under torment by the devil, people who go from crisis to crisis, people under demonic oppression and attack. It includes sickness, poverty and other forms of economic oppression. (p. 277)

In the New Testament, various terms provide understanding to the purpose and significance of miracles in the ministry of Jesus. Tepas (teras) means 'wonder.' The Greek term teras is never used by itself for miracles but always in conjunction with other words or terms such as 'signs', 'powers' or 'mighty works' (Ac 2:43, 2:22). The term emphasises the fact that people usually manifested great astonishment at the miracles of Jesus. The wonder which the miracles produced on the people revealed the extraordinary nature of the miracles (Dickson 2012):

Since miracles were given for the purpose of confirming the messengers and message of God, then they had to be so obvious that they would cause the beholders to be amazed at their occurrence. If the miracle does not cause (teras) in the mind of the audience, then the very purpose for miracles is denied because the happening is questionable. (p. 1506)

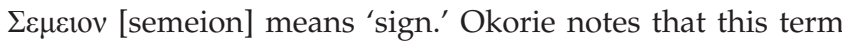
is generally in plural semeia [signs] ... a Johannine nuance stressing the significance of the action rather than the marvel as in John 2: 11, 4:54, 6:2.

Richard Trench avers that a sign is a token and indication of the near-presence and working of God. The miracles of Jesus pointed at something beyond the observable. They are 'tokens of God's presence and of the sanction, thus afforded to the teacher or what is taught' (Trench 1968:4). Beyond causing amazement, miracles point behind the actions conveying the message of approval by God, hence his presence. The miracles of Jesus were given as proof of his person and the trustworthiness of his claims. On this basis, Christ rebuked the crowd who followed him for missing out on the message that the miraculous feeding of the five thousand was meant to convey. 'You are looking for me not because you saw miraculous signs that because you ate the loaves and were filled' (Jn 6:36).

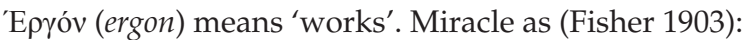

$[W]$ orks was meant to convince man of his divinity. The term 'ergon' seems to convey the thought that the miracles, as wonderful acts to man, were manifestations of the natural environment in which Jesus lived before his incarnation. (p. 10)

Jesus belonged to the supernatural realm and had total command of that realm. The miracles of Jesus revealed his divine personality. Miracles were given as proof of the trustworthiness of his person and message. They were not meant to cook wonder in the minds of the beholders (Onwu 2002):

k. The healing miracles are part of the proclamation of the
kingdom of God, they are designed not for amazement, not for
personal popularity but to awaken repentance, to create deeper
and understanding of his person, and to generate a deeper sense
of commitment to him. (p. 195)

$\Delta v v \alpha \mu 1 \varsigma$ [dunamis] mean 'power', 'might', 'strength,' 'force.' When used in reference to miracle, the reference is to the quality or authority of the messenger. The term 'power' is definitive of divine power manifested in that which was wrought, as well as the divine nature in the one who performed the deed. The miracle was the manifestation of the divine in the performer (Dickson 2012:1506).

The miracles of Jesus were not performed for themselves. They were an integral part of the proclamation of the kingdom of God with the associated call to repentance towards God and faith in his revealed son. His was not premeditated and advertised miracle crusades rather whenever miracles were performed, it was in the course of his preaching, and teaching. 'These miracles were not premeditated calculations. From the general literary analysis, 
wherever the word "compassion" appeared it was always associated with expediency rather than premeditation' (Okorie 2012:192). The miracles of Jesus encouraged the hopeless to have faith in God. The sick who had become resigned to their sickness were encouraged to believe that they could and would be cured. Miracles became a source of strength and hope.

\section{Marks' portrait of Jesus in the pericopae and the African perception of a saviour}

In the pericope, Mark's Jesus is acknowledged by the leper as worthy of worship, respect and trust.

Therefore, he approaches Jesus with a deep sense of humility. The posture of kneeling to present his request implies that the leper is not in doubt of the superiority and authority of Christ over his predicament. Jesus' response to the leper, 'I will, be clean', reveals him as one who does not need to consult a higher authority in order to save and liberate. He touches the unclean leper and yet is not made unclean. The purity of Christ swallows up the impurity of the unclean, leaving the unclean clean. This testifies to the supernaturalness of Christ. Christ initiates restoration by sending him away to the priest. The leper is liberated from his bondage to the religious laws that restricted him, but had no power to save him. He is liberated to return to normal life and fellowship with the community of God:

Liberation should be understood in its totality, as removal of all that keeps the African man in bondage, all that makes him less than what God wants him to be. (Ngele 2008:32)

This is what Jesus has done for the leper.

In African cosmology, whatever happens to the human being is interpreted spiritually. To the African, behind the physical is the spiritual. It is believed that the forces of evil are always at work, causing misfortunes, sickness, poverty, crisis and hindrances in order to prevent humans from enjoying abundant life. Within the world of humans are men and women who manipulate the spiritual for evil purposes. Uncertainties of life propel the African's search for divine intervention - one who is powerful and able to rescue him from the cause of his fears. According to Odudoye, 'the rescuer plucks you from a dehumanizing ambience and places you in a position where you can grow toward authentic humanity' Oduyoye (1998:23).

A 'Saviour' in African self-understanding is, therefore, one who is able to save, rescue, liberate, deliver and protect. 'Christ cannot be relevant to Africans if he is unconcerned about their social, political, economic and spiritual realism of existence' (Onwu 2002:278). Marks' portrait of Jesus appeals to this perception. Such a saviour must be approachable, humble, selfless and with power. It is in this context that the charge to silence can make meaning to Africans.

\section{The command to silence: An African context}

The miracles of Jesus revealed the extraordinariness of Jesus' person and power. The amazement and wonder evoked by these miracles drew large crowds of followers. Africa is suffering at the hands of many oppressive aspects. Healing and protection therefore constitute the greatest attraction to Africans.

It may be asserted that 'in Africa there is a tendency to run to God for succour in the time of need and insecurity' (Obi 2012:210). The yearning for true liberation in Africa is high. Ituma (2000) captures the atmosphere in these words:

Once you are able to heal the sick ... the people are yours. Nobody really cares about what you preach. Nobody cares about your interpretation of the scriptures. People have so many problems they will go any extent with you. They will do almost whatever you tell them to do. (p. 74)

Most preachers attach much importance to material things, such as money, more than their eternal life in heaven and the materialistic gospel preachers have unfortunately taken advantage of the general poor Bible reading habits of most people (Nwadialor \& Umeanolue 2013:31).

The ministry of Jesus with this astounding achievement would have been a platform for self-glorification, ostentatiousnesss, hero worship and exploitation. Jesus resisted the temptation to go in that direction. Consequently, the charge to silence in African understanding reveals the virtue of humility demonstrated in approachability, selfless service and compassion. It calls the attention of the followers of Jesus to the worthiness of emulating such a life style as a pattern for service to God and man.

\section{Approachability}

Jesus welcomed all people and was willing to engage in conversation with them. He did not hold himself aloof from sinners, tax collectors and prostitutes or to the self-righteous religious leaders (Spurgeon 1868):

The most depraved and despised classes of society formed an inner ring of hearers around our Lord ... he was most approachable ... he courted human confidence and was willing that they should continue with him. (p. 67)

Although born a Jew, Jesus engaged in communication with Gentile people who approached him. He broke through prejudices and cultural norms. He ignored both position and the fact that his mission had a primary target group: 'the lost house of Israel'. Among those who sat to listen to him were the most depraved and despised classes of society. The approachableness of Jesus contradicts 'the lofty ministerial airs that one has seen assumed by men who ought to have been meek and lowly'. Spurgeon (1868:67) 
This implies that one who is called to Minister Christ to a world in need must not allow position, prejudice or purpose to be a barrier to communicating Christ. It is noted that:

Position should not separate you. Jesus was willing to leave the glories of heaven behind and humble Himself to come to earth. Prejudices should not define you. Jesus broke through prejudices and cultural norms. He could be approach $[e d]$ by anyone without fear of rejection. Purpose should not isolate you. Jesus had a primary target group to whom He ministered. (Ministry Tools Resource Center n.y.)

\section{Selfless service}

The servanthood of the Christ in the divine pact of Messiahship was very clear to Jesus although the Jews had a contrary view. The humility of Jesus was proof of his acceptance and submission to his role as the servant king who came not to be served but to serve. This servant consciousness informed his relationship with God and man and subsequently his service to both. He saw his accomplishment as his responsible service which did not require self-glorification applause of men or personal enrichment. According to Onwu (2002):

This ... perspective reveals that Jesus shunned every temptation to self-glorification and exploitation wherever he performed miracles of healing. This is not the case with most African Christians who possess the power of healing. Instead most of them parade themselves in cities acclaiming their power of healing. (p. 71)

Selfless service recognises that everything we have is a free gift from God. It allows God to get all the credit for every achievement. It shuns rivalry and competitiveness.

\section{Compassion}

Humility serves as a catalyst for compassion. Ekwunife notes that humility is three-dimensional in the context of religious truth. Vertically, it establishes the link between man and God in a society. Horizontally, humility relates the humble man to his fellow human beings in any society and helps him organise his general behaviour accordingly; and, finally, there is the interior or inward dimension where reflections and evaluations of vertical and horizontal dimensions are made (Ekwunife 1995). The compassion of Jesus was not manifested in mere feelings or words, but in actions as he ministered to the needs of those upon whom he had compassion. Compassion informed his concern for the confused Jews as they sought to find direction for their lives. The humility of Christ propelled his compassion. His association and interaction with the afflicted, the oppressed, the sick, the poor, etc., enabled him appreciate their needs. In African morality, man is not innately good or bad, but judged in terms of what he does or does not (Park 2013):

This behaviour-oriented morality is not only a passive restraining of evil behaviours but active pursuing of righteous actions. Thus, African morality actively seeks such virtues as honesty, reliability... generosity temperance, humility and justice. (p. 182)

The charge to silence in African understanding draws attention to the virtue of humility and calls for emulation.

\section{Implication and challenges}

The situation in Africa is nothing different from the society in which Jesus ministered. The people are afflicted with hunger, poverty, sickness and diseases. There is insecurity. The weak are oppressed. There is the flaunting of affluence by the leaders, while hunger and poverty stare the masses in the face. The fear of witchcraft and wickedness possesses many. There is tension, which at times breaks forth into insurgencies. Africa is in dire need of liberation which is offered in the gospel of Jesus Christ. The Church in Africa must define its mission in this direction. According to Onwu (2002):

This means that the basic thrust of the church's ministry becomes a commitment to the liberation of the victims of unjust cultural, social, political, economic powers and structures of society. Thus liberation and reconciliation become the primary focus of the Church's ministry. (p. 278)

This power comes from God to people, enabling them to perform extraordinary works of power.

The task of liberation is an assignment that requires humility in the knowledge that man is only an instrument in the hands of God. Several of those who minister in the power of the Holy Spirit fail to realise that we are simply channels of the healing power of God (Ministry Tools Resource Centern.y.; Nwadialor \& Umeanolue 2013:29-44). Humility shuns self-advertisement, self-glorification, exploitation and competitiveness. Humility points to Christ and inspires faith and trust in him. Humility tames the tendency to claims of having solutions for every case and situation. Such claim engenders trickery, fraud and resorts to the diabolical for power display. The power consciousness of the African can only be satisfied as he is made to appreciate the role of the Holy Spirit in his daily living and encounters. Those who have responded to the message of the gospel should be led to experience the liberating power of the Holy Spirit for themselves, and to live in the consciousness of this power.

\section{Recommendation}

1. African people yearn for liberation from the oppressing forces that afflict them. The task of liberation can only be achieved by the power of the Holy Spirit. The demand places a solemn call to the ministers of the gospel for a deeper commitment to seeking God for the endowment of the power.

2. Miracles should be seen and regarded as an integral aspect of the proclamation of the gospel. They may not be taken in isolation and emphasised at the expense of the transforming power of the gospel of Jesus Christ. Miracles can, rather than advance the cause of the gospel, become a hindrance if not put in proper perspective.

3. The Body of Christ (the church) should be enlightened to understand that miracles are a sign of the presence of God among us. They are not to be taken as bestowing any particular status on the performers. 
4. All who are engaged and involved in the spreading of the good news of Jesus Christ must allow the example of Jesus to become a pattern for lifestyle and service. The humility of Jesus must be reflected in the approachableness, selfless service and compassion of the servant of Christ.

\section{Conclusion}

The secrecy motif in Mark 1:40-45 makes meaning to the African only when the text is examined in the context of African self-understanding and experience. The motif of secrecy calls the church's attention to a balanced focus in its mission to the African society. Miracles and healings form an integral part of the kingdom message and should not be performed in isolation. Miracles are a sign of the presence of God; they may not be taken as bestowing a certain status on the performer. If miracles are wrought by the power of God, they must serve the particular purpose for which they are given as in biblical times.

The secrecy motif sets a pattern for the lifestyle of all those who are called to Minister Christ to the world. It highlights the humility with which Jesus carried out the miracle ministry and a lesson for the followers. Africans are faced with too many problems, including acute poverty, sickness, demon possession, injustice and suppression of the poor. When a Christian offers himself or herself to be used by God to perform miracles and to release people from various forms of bondage, it should not call for selfglorification, self-advertisement and exploitation. Jesus' secrecy motif of Mark should be a lesson for the African preacher.

\section{Acknowledgement}

The authors thank HTS and their staff. God bless you for your efforts.

\section{Competing interest}

The authors have declared that no competing interests exist.

\section{Authors' contributions}

E.T. is the pioneer and supervisor during the process of the research. He constructed the thesis of the article. S.E. and F.C.U. were part of the fieldwork of the research. They were sourced useful manuscripts and extra-biblical materials to back up the proposed thesis.

\section{Ethical consideration}

This article followed all ethical standards for a research without direct contact with human or animal subjects.

\section{Funding information}

This research received no specific grant from any funding agency in the public, commercial or not-for-profit sectors.

\section{Data availability statement}

Data sharing is not applicable to this article as no new data were created or analysed in this study.

\section{Disclaimer}

The views and opinions expressed in this article are those of the authors and do not necessarily reflect the official policy or position of any affiliated agency of the authors.

\section{References}

Aland, B., Aland, K., Karavidopoulos, J., Metzger, B.M. \& Martini, C.M., 2006, The Greek New Testament, 4th revised edn., p. 122, Deutsche Bibel-gesellscha ft, D-Stuttgart, Hendrickson, Peabody.

Alcott, L.M., 2011, 'Quotes' viewed 18 November 2011, from https://www.goodreads. com/user_quotes/11383041.

Anver, V., 2018, 'Nigeria: A heap of contradictions', Newafricanmagazine, October 11.

Aviam, M., 2013, 'People, Land, Economy, and Belief in First-Century Galilee and Its Origins: A comprehensive Archaeological Synthesis,' In A.F. David \& R.K. Hawkins (eds.), The galilean economy in the time of Jesus, no. 11, p. 5.

Babatope B., 2018, Nigeria and leadership challenge, viewed 16 April 2018, from https://www.sunnewsonline.com/nigeria-and-leadership-challenge/.

Case S., 1923, 'The art of healing in early Christian times'. The Journal of Religion 3, no. 3, pp. 238-255.

Dibelius, M., 1982, From tradition to Gospel, p. 24, James Clarke \& Co., Cambridge.

Dickson J., 2008, 'Was Jesus' Miracle Work Unique?', viewed 11 June 2008, from https://www.publicchristianity.org/was-jesus-miracle-work-unique/

Dickson, R.E., 2012, Dickson Biblical Research Library, p. 1506, Africa International Missions, Kansas.

Dunn, J.D., 1970, The messianic secret in Mark, p. 97, Tyndale House, Cambridge, London.

Dunn, J.D., 1971, The messianic secret, James Clarke \& Co. Ltd., Cambridge, London.

Ekwunife, A.N.O., 1995, Spiritual explosions reflections on Christian lives and practices in Nigerian context, p. 83, SNAAP Press Ltd., Enugu, Nigeria.

Finley, M.I., 1999, Ancient economy, 2nd edn., updated Edition with a foreword by I. Morris, Sather Classical Lectures 43, University of California Press, London.

Fisher, G.P., 1903, Manual of Christian evidences, p. 10, Charles Scribner's Sons, New York.

Goodacre, M., 2010, NT Pod Extended Episode 4: The messianic secret in Mark's Gospel, viewed 02 February 2015, from http://podacre.blogspot.com.

Greig, F.C.G., 1971, William Wrede: The messianic secret, p. 11, James Clarke \& Co. Cambridge, London.

Gwamma, J.D., 2008, Perspectives in African theology, p. 136, African Christian Textbooks, Bukuru, Nigeria.

Häkkinen, S., 2016, 'Poverty in the first-century Galilee', HTS Teologiese Studies/HTS Theological Studies 72(4), a3398. http://dx.doi.org/10.4102/hts.v72i4.3398

Hamil, B.R., 2011, A brief introduction to the messianic Secret in the Gospel of Mark, viewed 20 November 2015, from https://www.academia.edu/529866/A Brief_Introduction_to_the_Messianic_Secret_in_Mark.

Hanson, K.C. \& Oakman, D., 1998, Palestine in the time of Jesus: Social structure and social conflicts, 2nd edn., Fortress Press, Minneapolis, MN.

Henry, M., 2011, Matthew Henry's commentary on the whole Bible, Hendrickson Publishers, Peabody.

Ituma, E.A., 2001, Welcome to the New Testament writing, p. 104, Chinedum Publishers Ltd, Lagos, Nigeria.

Keith, B.H., 1970, 'To Give up on Words: Silence in Western Apache Culture. Southwestern Journal of Anthropology 26(3), 213-230.

Kudasiewicz, J., 1996, The synoptic Gospels today, p. 13, Alba House, New York.

MacLaren, A., Exposition of the Holy Scripture: Mark, viewed 13 January 2014, from https://books.google.com.ng/books.

Matthew, S.P., Jesus and the purity system in Mark's Gospel: A leper (Mark 1:40-45) viewed 04 February 2014, from http:www.biblicastudies.org.uk

Meier, J.P., 1994, A marginal Jew: Rethinking the historical Jesus, vol. 2: Mentor message, and miracles, Doubleday, New York.

Ngele, O.K., 2008, 'The quest for African Christology: Towards a redefinition of Jesus in African context and faces', Journal of Religious Studies 2(1), 65.

Nwadialor, K.L. \& Umeanolue, I.L., 2013, 'Materialistic gospel message in contemporary Nigerian churches: A critique', Journal of Religion and Human Relations 1(5), 29-44.

Oakman, D.E., 2008, Jesus and the peasants, matrix: The Bible in Mediterranean context, Cascade Books, Eugene, OR.

Obi, C.A., 2012, 'Healing miracles in the Acts of the Apostles: A spring board for Pentecostal propaganda', Biblical Study Series, Biblical Healing in African Context p. 210, Nigerian Association for Biblical Studies, Ibadan.

Oduyoye, M., 1998, Hearing and knowing, p. 98, Orbis Books, New York. 
Okorie, A.M., 2012, The healing miracles of Jesus in the African context, Biblical Healing in African Context 3, p. 192, Nigerian Association for Biblical Studies, Ibadan.

Onwu, E.N., 2002, A critical introduction to the traditions of Jesus, p. 66, AP Express Publishers, Nsukka.

Overman, J.A., 1997, 'Jesus of Galilee and the Historical Peasant', Archaeology and the Galilee, in D.R. Edwards \& C.T. McCollough (eds.), pp. 67-74, Scholars Press, Atlanta.

Oyeshola, D., 2007, 'Development And Poverty: A Symbiotic Relationship And Its Implication In Africa', African Journal of Traditional and Complementary Medicine $4(4)$, pp. 553-558.

Panagiotidou, O., 2016, 'Religious healing and the Asclepius cult: a case of placebo effects.' Open Theology, 2(1), pp. 79-91.

Park, S.K., 2013, Christian spirituality in Africa: Biblical, historical, and cultural perspectives from Kenya, p. 182, Stock Publishers, Nairobi.

Peek, P.M., 1994, 'The sounds of silence: crossworld communication and the auditory arts in African societies'. American Ethnologist 21(3), 474-494.

Pilch, J.J. \& Malina, B., 1998, Handbook of Biblical social values, p. 118, Hendrickson Publishers, Peabody.

Richards, J., 1983, Mark's Naunce of Wrede's Messianic Secret, The Messianic Paradox, viewed 02 March 2015, from http:www.western.thmwordpress-compdf.

Sanday, W., 1907, The life of Christ in recent research, p. 100, Oxford University Press, New York.
Sobkowiak, W., 1997, 'Silence and the markedness theory'. In A. Jawarski (ed.) Silence: Interdisciplinary perspectives, Berlin: Mouton de Gruyer.

Spurgeon, C.H., 1868, The approachableness of Jesus, viewed 11 January 2014 from http://www.iclnet.org/pub/resources/text/history/spurgeon/web/ss-0007. html.

Taylor, V., 1953, The formation of the Gospel tradition, p. 195, Macmillan \& Co. London.

Ter Haar, G., 2003, 'A wondrous God: Miracles in contemporary Africa.' African Affairs 102, no. 408, pp. 409-428.

Trench, R.C., 1968, Notes on the Miracles of our Lord, p. 4, Baker Book House, Grand Rapids, MI.

Ucha, C., 2010, 'Poverty in Nigeria: Some Dimensions and Contributing Factors,' Global Majority E-Journal 1(1), 47.

Widowfield, T., 2013, What is the messianic secret?, viewed 23 January 2015, from http:www.vridar.og/2013/01/03what-is-the-messianic secret.

Wright, N.T., 1996, Jesus and the victory of God: Christian origins and the question of God, p. 529, Fortress Press Ltd., Minneapolis, MN.

Yancy, K.B. \& Spooner, M., 1994, 'Concluding the text: Notes toward a theory and practice of the voice'. In K.B. Yancy (ed.), Voices on voice: Perspectives, definitions, inquiry, pp. 298-314, Urbana, IL: NCTE. 